\title{
BeleidsonderzoekOnline
}

\section{Kansen en barrières voor implementatie van de landelijke Handreiking Gezonde Gemeente in de GGD- organisatie}

Theo J.M. Kuunders, Ien A.M. van de Goor, Theo G.W.M.

Paulussen, Marja J.H. van Bon-Martens en Hans A.M. van Oers

\author{
Aanbevolen citeerwijze bij dit artikel \\ Theo J.M. Kuunders, Ien A.M. van de Goor, Theo G.W.M. Paulussen e.a. , \\ 'Kansen en barrières voor implementatie van de landelijke Handreiking \\ Gezonde Gemeente in de GGD-organisatie', Beleidsonderzoek Online mei \\ 2015, DOI: 10.5553/BO/221335502015000018001
}

\section{Introductie}

In 2005 concludeerde de Inspectie voor de Gezondheidszorg (IGZ) dat bij lokale overheden een gerichte en systematische aanpak van de volksgezondheidsproblemen ontbrak, en dat de kwaliteit van de lokale openbare gezondheidszorg moest worden verbeterd. In het rapport werd gepleit voor het ontwikkelen van een krachtige professionele standaard op het gebied van gezondheidsbevordering door Gemeentelijke Gezondheidsdiensten (GGD), en voor 'versterking van het integrale kwaliteitsmanagement' door GGD-directies (IGZ, 2005). Ter ondersteuning van de professionalisering van het gemeentelijk gezondheidsbeleid brachten de landelijke thema-instituten voor gezondheidsbevordering vanaf 2006 handleidingen (richtlijnen) uit. Daarin werd op basis van de best beschikbare kennis beschreven hoe het lokaal gezondheidsbeleid op deelterreinen meer 'evidence based' kon worden vormgegeven. De eerste handleiding betrof de 'Tabakspreventie in de nota Lokaal Gezondheidsbeleid' (Stivoro, 2006). Daarna volgden handleidingen voor de preventie van overgewicht (Voedingscentrum, 2007), alcohol (Voedsel en Warenautoriteit, 2007) en depressie (Trimbos-instituut, 2007). Om het gemeentelijk gezondheidsbeleid op deze thema's te verbeteren adviseerde de IGZ in 2010 de handleidingen intensiever te gebruiken (IGZ, 2010). Dit advies volgde op een evaluatie van de handleidingen 
door het RIVM in 2009 (Van Dijk \& Van Kesteren, 2009), waaruit bleek dat gemeenten de handleidingen meestal slechts gebruikten als achtergrondinformatie. Redenen die genoemd werden voor het beperkt gebruik, waren dat GGD-en en gemeenten informatie misten over de effectiviteit van de aanbevolen interventies en welke interventies elkaar konden versterken. GGD-en misten ook voorbeelden van een integrale benadering waarbij een heldere rolverdeling tussen partijen in gezondheidsbevordering is afgesproken (Van Dijk \& Van Kesteren, 2009: 5-6).

In 2010 kwam het RIVM aan de kritiek uit de evaluaties tegemoet met de vernieuwde 'Handreiking Gezonde Gemeente' (hierna: 'handreiking'), bestaande uit een samenvoeging van de herziene versie van de vier handleidingen, aangevuld met nieuwe thema's (Stivoro et al., 2010) en met tools voor een integrale benadering. De ontwikkelaars kozen voor de verschuiving van 'handleiding' naar 'handreiking', omdat de term 'handleiding' een 'vast recept voor gemeentelijk gezondheidsbeleid' suggereert dat aan de pluriforme praktijk onvoldoende recht zou doen (Loketgezondleven.nl, 2014). Een centraal uitgangspunt in de handreiking is dat het beleid zich bij voorkeur gelijktijdig richt op meerdere determinanten van (on)gezondheid (Lalonde, 1974). Voor dat beleid gebruikt de handreiking de term 'integraal beleid'. Dit beleid richt zich op gezondheid van het individu in wisselwerking met zijn of haar fysieke en sociale omgeving, waaruit volgt dat meerdere gemeentelijke sectoren kunnen bijdragen aan het al dan niet bereiken van publieke gezondheidsdoelen.

De handreiking is in feite de professionele standaard voor gezondheidsbevordering op lokaal niveau waarmee de GGD de kwaliteit van zijn adviestaak voor het gemeentelijk gezondheidsbeleid zou kunnen verhogen, waar de IGZ in 2005 voor gepleit heeft. De implementatie van de handreiking binnen de GGD-en verloopt echter nog moeizaam. Professionals zijn onvoldoende in staat of worden onvoldoende in staat gesteld om het huidige aanbod naar hun lokale praktijk te vertalen en hebben behoefte aan meer handvatten voor het inpassen van interventies (Kwink Groep: Noordink, 2013: 6-7).

Uit implementatietheorie en empirisch onderzoek blijkt dat het succes en falen van de invoering van innovaties niet enkel bepaald wordt door de intrinsieke kwaliteitskenmerken van de innovatie die wordt aangeboden, maar ook door verschillende pragmatische en contextuele factoren (Van Linge, 2006: 16). Voorts kan verondersteld worden dat de inrichting van beleidsprocessen binnen de betreffende GGD-organisatie van invloed is op de mate waarin de handreiking bij de GGD-en geïmplementeerd wordt.

De centrale vraag voor dit onderzoek is welke factoren in de beleidsen uitvoeringspraktijk van de GGD de adoptie en het gebruik van de 
Handreiking Gezonde Gemeente belemmeren of bevorderen.

\section{Methode}

\section{Ontwikkeling raamwerk}

Voor dit onderzoek is een raamwerk ontwikkeld dat is ontleend aan recent empirisch onderzoek naar en theorieën over de diffusie van innovaties (Paulussen et al., 2012). Deze diffusietheorieën zoeken vanuit de innovatie naar specifieke factoren en kenmerken die de invoering van innovaties positief dan wel negatief beïnvloeden (Rogers, 2003: 169). Het genoemde empirisch onderzoek wijst op bevorderende en belemmerende factoren voor adoptie en gebruik van innovaties en onderscheidt vier categorieën van factoren. Deze categorieën van factoren hebben we voor het raamwerk met de categorie 'management' aangevuld en inhoudelijk ingevuld op basis van inzichten uit twee voor dit onderzoek relevante aanvullende wetenschapsgebieden: de beleidswetenschappen (omdat de handreiking betrekking heeft op een specifiek beleidsveld) en de organisatiekunde (omdat de GGD als netwerkorganisatie in het beleidsveld voor gezondheidsbevordering een centrale positie inneemt). Het in dit onderzoek gebruikte raamwerk is gebruikt als kader voor kwalitatieve interviews en bestaat uit de categorieën:

1. de organisatie;

2. de individuele gebruiker: kennis, attitude, vaardigheden en sociale en omgevingsfactoren;

3. het management;

4. de innovatie;

5. de sociaal-politieke omgeving.

De beleidswetenschappen interpreteren innovaties vanuit de beleidscontext, voor dit onderzoek het kader van het landelijke en lokale gezondheidsbeleid. Bij implementatie van de handreiking gaat het om lokale doorvoering van landelijk vastgestelde beleidsdoelen, waarbij de sociaal-politieke omgeving, bestuurlijke verhoudingen en verhoudingen tussen lokale en regionale organisaties als beleidscontext een belangrijke rol spelen. Voor de interpretatie van deze beleidscontext gebruiken we de 'configuratiebenadering', die in Nederland door Termeer et al. (2006) werd geïntroduceerd en gebaseerd is op de organisatietheorie van Weick (1969/1979). Niet de organisatie als duidelijke structuur staat bij Weick centraal, maar handelende mensen die, geconfronteerd met de praktische vraagstukken van het organiseren, zin proberen te geven aan de 
situaties waarin zij verkeren en die zij gedeeltelijk zelf oproepen (Kerkhoff, 2006: 89-90; Hoppe, 1999). Deze aanname is voor de GGD van belang. De GGD bevindt zich als gemeentelijke dienst in een lokaal en regionaal beleidsnetwerk en kan getypeerd worden als netwerkorganisatie (Bekker \& Putters, 2003). De handreiking spreekt de GGD aan op zijn praktijkrol als initiator en ondersteuner van integraal beleid en sectoroverstijgende samenwerking tussen gemeentelijke beleidsterreinen, waaronder sectoren die niet direct gezondheidsdoelen nastreven. Om die rol te spelen moeten de GGDprofessional en -manager kunnen omgaan met verschillende perspectieven en samenwerkingsprocessen kunnen faciliteren en configureren. In welke mate deze randvoorwaarden binnen de GGD ingevuld zijn, is een vraag voor dit onderzoek. Het antwoord kan verhelderend zijn voor de mate van aansluiting van de handreiking op de bestaande GGD-werkwijzen.

Een tweede aanname uit de beleidswetenschap is dat de vrijheid die professionals hebben om een vernieuwing al dan niet te gebruiken, de zogenoemde 'discretionaire ruimte' (Coolsma, 2003), een belangrijke factor is voor het succesvol implementeren van een nieuwe richtlijn. Verwacht wordt dat voor GGD-professionals in een netwerkorganisatie de discretionaire ruimte groot is, vanwege de continue afstemming op lokale verschillen en mogelijkheden van individuele gemeenten. Daarom zal bij implementatie van de handreiking gezocht moeten worden naar hun beloningsoriëntaties Paulussen et al., 2012): wat is de meerwaarde die het gebruik van de handreiking hun persoonlijk of als professional biedt, dus wat motiveert of stimuleert hen tot adoptie en gebruik van de handreiking en hoe verhouden zij zich tegenover de competenties die de handreiking veronderstelt?

De organisatiekunde biedt inzichten die wijzen op het belang van management- en beleidsprocessen in en tussen organisaties bij het invoeren van innovaties, met name daar waar verondersteld wordt dat innovatiedoelen in coalitieverband gerealiseerd worden. Uit de organisatiekunde zijn uitgangspunten van Weggeman en Mintzberg gebruikt over de rol van het management in kennisintensieve organisaties: in dit type organisaties is een goed evenwicht nodig tussen collectieve ambitie aan de ene kant en regels en procedures aan de andere (Weggeman, 2008: 17-18). Twee stellingen van Mintzberg zijn hier richtinggevend: 'Managing without an intimate understanding of what is being managed is an invitation to disharmony. External linking and dealing cannot be dissociated from internal leading and doing' (Mintzberg, 1998). De GGD is een organisatie met hoogopgeleide kenniswerkers. Het sturen van kenniswerkers moet volgens Weggeman voortkomen uit een collectieve ambitie die aansluit bij de professionele waarden en niet uit een verticaal controlemechanisme (Weggeman, 2003). De leidinggevende vertaalt met de professionals de ambitie naar afgeleide 
haalbare en uitdagende groepsdoelen. De uitdaging geldt temeer, omdat er GGD-en opereren binnen coalities van partijen die gezamenlijk hun doelen willen realiseren. Het evenwicht tussen collectieve ambitie en regels in de GGD-en wordt derhalve meegenomen in het onderzoek.

\section{Onderzoeksopzet}

Omdat nog weinig onderzoek is verricht naar determinanten die de implementatie van innovaties zoals de handreiking bij de GGD-en bevorderen of belemmeren, is gekozen voor een exploratieve empirische verkenning, bestaande uit kwalitatieve, semigestructureerde interviews. Voor de bepaling van de interviewtopics en voor analyse van de interviewdata hebben we het ontwikkelde kader (vijf categorieën op basis van het verklaringsmodel van Paulussen et al., 2007, hoofdstuk 7 en 10) aangevuld met de hierboven genoemde perspectieven uit de beleids- en organisatietheorie (tabel 1).

Tabel 1 Kader voor analyse bevorderende en belemmerende factoren

\begin{tabular}{|c|c|}
\hline $\begin{array}{l}\text { Kader } \\
\text { determinanten } \\
\text { verspreiding } \\
\text { innovaties }\end{array}$ & $\begin{array}{l}\text { Perspectieven uit beleids- en } \\
\text { organisatiewetenschappen }\end{array}$ \\
\hline $\begin{array}{l}\text { Interne } \\
\text { organisatie }\end{array}$ & $\begin{array}{l}\text { Mate van sturing op collectieve } \\
\text { ambities/stimulering vs. beheersing } \\
\text { Mate van explicitering organisatiedoelen } \\
\text { Evenwicht interne/externe gerichtheid }\end{array}$ \\
\hline $\begin{array}{l}\text { Individuele } \\
\text { gebruiker }\end{array}$ & $\begin{array}{l}\text { Kennis, competenties en leerklimaat; } \\
\text { experimenteerruimte en informatie- } \\
\text { uitwisseling gebruikers handreiking } \\
\text { Mate van beleidsvrijheid bij professionals } \\
\text { Mate van explicitering } \\
\text { beloningsoriëntatie beoogd gebruiker } \\
\text { Teamcommitment en -ondersteuning }\end{array}$ \\
\hline
\end{tabular}




\begin{tabular}{|c|c|}
\hline $\begin{array}{l}\text { Betrokkenheid } \\
\text { management }\end{array}$ & $\begin{array}{l}\text { - Inhoudelijke kennis van en } \\
\text { sturing op innovatie (type } \\
\text { managementstijl) } \\
\text { - Heldere verticale communicatie } \\
\text { over ambities (integraal beleid) } \\
\text { - Mate van explicitering } \\
\text { beloningsoriëntatie manager } \\
\text { - Beloning professional voor } \\
\text { gebruik innovatie }\end{array}$ \\
\hline $\begin{array}{l}\text { Innovatie } \\
\text { (Handreiking) }\end{array}$ & $\begin{array}{l}\text { Mate van procedurele helderheid en } \\
\text { concrete toepasbaarheid op de praktijk } \\
\text { Mate van kwalificering innovatie als } \\
\text { professionele standaard } \\
\begin{array}{l}\text { Mate van afwijking handreiking van } \\
\text { bestaande werkwijzen GGD }\end{array}\end{array}$ \\
\hline $\begin{array}{l}\text { Omgeving, } \\
\text { sociale/politieke } \\
\text { context }\end{array}$ & $\begin{array}{l}\text { Communicatie over betekenis centrale } \\
\text { concepten innovatie (i.c. integraal beleid) } \\
\text { Complexiteit besluitvorming in netwerk } \\
\text { Beschikbare middelen } \\
\text { Mate van heen-en-weer denken tussen } \\
\text { beleidsontwerp en praktische } \\
\text { beleidsvoering } \\
\text { Mate van interactie over bijdrage } \\
\text { gezondheidsdoelen aan andere } \\
\text { partijen/gemeentelijke sectoren }\end{array}$ \\
\hline
\end{tabular}

Interviews zijn afgenomen bij twee GGD-en. De GGD-en werden gekozen vanwege hun onderlinge vergelijkbaarheid als regionale GGD en vanwege hun betrokkenheid bij een proef-implementatie van de handreiking. De resultaten van de interviews dienden als bouwstenen voor een implementatiestrategie. We hebben purposive sampling (Boeije, 2006: 50) toegepast om ervoor te zorgen dat verschillende 
functiegroepen binnen de GGD-en vertegenwoordigd waren. GGDbeleidsmedewerkers zijn bewust oververtegenwoordigd omdat zij nauw bij de ontwikkeling van de gemeentelijke gezondheidsnota betrokken zijn en geacht worden daarbij de handreiking als hulpmiddel in te zetten. Aangenomen wordt dat de adoptie van een innovatie binnen een organisatie succesvoller verloopt naarmate meer functies bij de invoering betrokken zijn. Daarom zijn binnen één GGD interviews afgenomen bij alle relevante functieniveaus in de organisatie, zodat een samenhangend beeld binnen de gehele organisatiestructuur verkregen werd.

Daarnaast zijn van de betreffende steden- en regiogemeenten twee beleidsambtenaren volksgezondheid geïnterviewd om hun mening over de invoering van de handreiking te achterhalen. Tot slot zijn drie respondenten buiten de GGD-organisatie gekozen die vanuit een intensieve samenwerkingsrelatie met de GGD een extern gezichtspunt inbrengen over de positie van de GGD in het netwerk van gemeenten en Public Health partners: een beleidswetenschapper/Public Health expert, een trainer/consultant en een van de ontwikkelaars van de handreiking met landelijke kennis van de GGD-organisatie.

In totaal zijn veertien interviews afgenomen bij twee GGD-en, twee gemeenten en externe respondenten (tabel 2).

Tabel 2 Overzicht organisaties en respondenten

\begin{tabular}{|l|l|}
\hline Organisatie & Discipline \\
\hline Gemeenten (stedelijk) & Ambtenaar VG \\
\hline Regiogemeente (platteland) & Ambtenaar VG \\
\hline GGD-en & \\
\hline GGD A & Manager \\
\hline & Teamleider \\
\hline & Beleidsfunctionaris \\
\hline & Beleidsfunctionaris \\
\hline & Beleidsfunctionaris \\
\hline & Directeur \\
\hline GGD B & GVO-functionaris \\
\hline & Manager \\
\hline Niet GGD & Beleidsfunctionaris \\
\hline Universiteit & \\
\hline & $\begin{array}{l}\text { Beleidswetenschapper Public } \\
\text { Health expert }\end{array}$ \\
\hline
\end{tabular}


Management

consultancybureau
Trainer/consultant gemeentelijke beleidsondersteuning

Ontwikkelaar Handreiking

\section{Analyse en dataverzameling}

De interviews werden in 2010 en januari 2011 afgenomen. Na een pretest is de definitieve topiclijst vastgesteld (tabel 3).

De interviews zijn getranscribeerd en vervolgens gecodeerd in Atlas Ti (Friese, 2012). Na codering zijn 413 unieke codes ingedeeld in 18 categorieën. Om intersubjectiviteit van het codeersysteem te bereiken is een inter-beoordelaarscontrole uitgevoerd. De hoofdonderzoeker en twee senior onderzoekers hebben onafhankelijk van elkaar vijf geanonimiseerde interviews gecodeerd. Na twee controlesessies van in totaal zes interviews werd overeenstemming bereikt over het coderingssysteem.

Tabel 3 Topiclijst interviews onderzoek implementatie Handreiking Gezonde Gemeente

Centrale vraagstelling

Hoe worden de landelijke handleidingen voor gezondheidsbevordering door de GGD gebruikt bij de ondersteuning van gemeenten en lokale uitvoeringspartners?

Wat zijn bepalende belemmerende/bevorderende factoren bij implementatieprocessen op lokaal niveau van de:

a) feitelijke processen binnen GGD-organisatie zelf?

b) in de relatie tussen GGD en gemeenten en andere partijen voor gezondheidsbevordering?

1. Wil je iets vertellen over je huidige functie?

2. Ben je bekend met de landelijke handleidingen voor gezondheidsbevordering?

3. Hoe kwamen (komen) de handleidingen binnen in de organisatie (GGD/gemeente)?

4. Kun je iets vertellen over je eigen ervaringen met de handleidingen?

Wat vind je van de bruikbaarheid? 
5. Merk je dat managers, teamleiders, collega's (wel of niet) achter het gebruik van de handleidingen staan? Hoe merk je dat?

6. Waar ligt de belangrijkste taak voor de adviseurs lokaal gezondheidsbeleid ideaal gesproken?

Wat zouden zij moeten doen? Wat zijn hun mogelijkheden voor het werken met de handleidingen?

7. Welke faciliteiten hebben GGD-medewerkers intern nodig om het gebruik van de handleidingen te verbeteren?

8. Wat wordt er tot nu toe door de teamleiders wel/niet gedaan met de handleidingen?

Waar heeft dit mee te maken?

9. Waar ligt de belangrijkste taak voor de teamleider gezondheidsbevordering ideaal gesproken?

Wat zouden zij moeten doen met de handleidingen?

10. Welke faciliteiten hebben teamleiders intern nodig om het gebruik van de handleidingen te verbeteren?

11. Welke belemmeringen of kansen zie je

a. in de werkwijze van de GGD-organisatie om te werken met de handleidingen?

b. in de samenwerking met de gemeenten om te werken met de handleidingen?

c. in de samenwerking met lokale organisaties?

12. Op welke manier zou voor jou het gebruik van de handleidingen binnen de organisatie (GGD/gemeente) iets toevoegen? En hoe schat je dit in voor anderen:

a. GGD collega in lokaal gezondheidsbeleid

b. Teamleider

c. Organisatie en management GGD

d. Gemeenten/samenwerkingspartners

\section{Resultaten}

De categorieën waarin de bijzondere uitspraken uit de interviews konden worden ondergebracht, zijn geordend naar het raamwerk (de vijf categorieën van factoren) voor verspreiding van innovaties (tabel 4).

Tabel 4 Overzicht categorieën op basis van analyse uitspraken 


\begin{tabular}{|c|c|}
\hline $\begin{array}{l}\text { Ordeningskader } \\
\text { determinanten } \\
\text { verspreiding innovaties }\end{array}$ & $\begin{array}{l}\text { Categorieën op basis van } \\
\text { resultaten interviews }\end{array}$ \\
\hline \multirow[t]{5}{*}{ Interne organisatie } & $\begin{array}{l}\text { Aansluiting bestaande werkwijze } \\
\text { GGD op integrale benadering } \\
\text { handreiking }\end{array}$ \\
\hline & $\begin{array}{l}\text { Beweegredenen GGD voor wel of } \\
\text { niet gebruik handreiking }\end{array}$ \\
\hline & $\begin{array}{l}\text { Interne afstemming } \\
\text { functieniveaus GGD }\end{array}$ \\
\hline & $\begin{array}{l}\text { Randvoorwaarden in organisatie } \\
\text { GGD voor gebruik handreiking }\end{array}$ \\
\hline & $\begin{array}{l}\text { Kansen en bedreigingen voor } \\
\text { integraal beleid }\end{array}$ \\
\hline \multirow[t]{4}{*}{ Individuele gebruiker } & $\begin{array}{l}\text { Kennis en vaardigheden voor } \\
\text { werken met handreiking }\end{array}$ \\
\hline & $\begin{array}{l}\text { Coaching voor gebruik } \\
\text { handreiking door GGD }\end{array}$ \\
\hline & $\begin{array}{l}\text { Eigen maken betekenis } \\
\text { handreiking voor eigen } \\
\text { werkwijze }\end{array}$ \\
\hline & Werk- en tijdsdruk \\
\hline \multirow[t]{3}{*}{$\begin{array}{l}\text { Betrokkenheid } \\
\text { management }\end{array}$} & $\begin{array}{l}\text { Visie GGD-management op } \\
\text { ondersteuning gemeentelijk } \\
\text { gezondheidsbeleid }\end{array}$ \\
\hline & $\begin{array}{l}\text { Verspreiding en onderhouden } \\
\text { kennis handreiking binnen GGD }\end{array}$ \\
\hline & $\begin{array}{l}\text { Rol manager en teamleider bij } \\
\text { gebruik handreiking door GGD }\end{array}$ \\
\hline \multirow[t]{2}{*}{ Innovatie (handreiking) } & $\begin{array}{l}\text { Kritische factoren voor gebruik } \\
\text { in handreiking zelf }\end{array}$ \\
\hline & $\begin{array}{l}\text { Vertrouwen in deskundigheid en } \\
\text { autoriteit makers handreiking }\end{array}$ \\
\hline \multirow[t]{2}{*}{$\begin{array}{l}\text { Omgeving, } \\
\text { sociale/politieke } \\
\text { context }\end{array}$} & $\begin{array}{l}\text { Afstemming rollen en } \\
\text { verantwoordelijkheden tussen } \\
\text { GGD en gemeenten }\end{array}$ \\
\hline & Beweegredenen gemeente voor \\
\hline
\end{tabular}


wel of niet gebruik handreiking

Afstemming met

samenwerkingspartners lokaal

gezondheidsbeleid

\section{Interne organisatie GGD}

Over de eigen interne GGD-organisatie en de verenigbaarheid van de handreiking met de bestaande werkwijzen doen dertien respondenten kritische uitspraken als 'achterhaalde of ontbrekende visie in de GGD, te aanbodgerichte werkwijze en geen overzicht over de eigen dienstverlening, onvoldoende interne afstemming en rigide urenplanning' (citaat 1). Aandacht voor de handreiking is volgens een beleidsprofessional verwaterd, waardoor de betekenis voor de organisatie wordt gemist.
1. En dat betreft ons aanbod, maar wat je daar verkoopt staat niet in relatie tot het bevorderen van een integrale aanpak want het zijn uren wat wij verkopen. Maar of die uren nou passen in het lokale gezondheidsbeleid, in die mix die gewenst is vanuit de door de gemeente gestelde doelen? Nee, het gaat er dan om dat wij in dat geval aanbieder willen zijn en eigenlijk staat het een beetje haaks op die gedachte van de handleidingen. (beleidsfunctionaris GGD 1)

Eén gezondheidsvoorlichter wijkt hiervan in positieve zin af. Zij vindt houvast in de voorbeeldteksten en interventies, maar vindt ook dat zij niet ver genoeg met aanbevelingen uit de handreiking kan meegaan, omdat er te weinig tijd voor gereserveerd is in het werkplan van de GGD.

Geïnterviewde managers in beide GGD-en spreken van een eilandcultuur, waardoor verschillende afdelingen onvoldoende weten van bestaande GGD-contacten met gemeenten of met netwerken die van belang zijn voor de ontwikkeling van sectoroverstijgend gezondheidsbeleid. Zowel respondenten uit GGD als gemeente vinden dat de kennis van de handreiking in logische samenhang met regionale beleidsondersteunende instrumenten (zoals de regionale Volksgezondheid Toekomst Verkenning) verankerd moet worden bij gemeenteambtenaren in lokaal gezondheidsbeleid.

\section{Individuele gebruiker van de handreiking}

Vijf respondenten denken dat 'door anderen bedachte interventies' uit de handreiking niet zonder meer passen in lokale processen van samenwerking en meedenkende burgers, wanneer mensen als onderdeel van draagvlakontwikkeling met elkaar willen bedenken welke kant ze op willen. Daarentegen noemen twee 
beleidsmedewerkers en de gezondheidsvoorlichter de behoefte aan concrete voorbeelden, die praktisch richting geven aan een aanpak van gezondheidsproblemen en die resultaten laten zien. Twee beleidsfunctionarissen en een gezondheidsvoorlichter vinden dat er tussen collega-professionals nauwelijks informatie wordt uitgewisseld over de beste aanpak of over de handreiking. Ook missen zij de inhoudelijke betrokkenheid vanuit teamleiders. Medewerkers en leidinggevenden weten soms niet dat de handreiking bestaat en waar die voor bedoeld is. Professionals bepalen grotendeels zelf of zij intern vastgestelde werkinstructies gebruiken. Daarnaast geven twee van hen aan dat ze er vaak alleen voor staan bij het uitwerken van preventieplannen. Daardoor is voor hen niet altijd duidelijk of ze op de goede weg zijn.

De managers van beide GGD-en en de beleidswetenschapper denken dat er aanvullende competenties nodig zijn om professionals beter te leren aansluiten bij referentiekaders van gemeenten en andere zorgaanbieders. Zij noemen bijvoorbeeld vaardigheden van 'procesmanagement'. Een beleidsfunctionaris verwacht dat coaching door teamleiders een passend antwoord kan bieden op de vraag hoe je professionals kunt aansturen via de handreiking, omdat daarin nieuwe vaardigheden gevraagd worden. Voor een dialoog met die omgeving wordt de specifieke competentie genoemd van evenwicht bewaren tussen je professioneel onafhankelijk oordeel als GGD en je laten leiden door belangen van de bestuurlijke omgeving (citaat 2).

\section{Maar dat is natuurlijk ook iets van hoe kijk je naar het gezondheidskundig model, en hoe relevant is de inbreng vanuit de omgeving voor het verder genereren van informatie die je gezondheidskundig ook kunt gebruiken. Dus op het moment dat je zeg maar informatie vanuit die bestuurlijke wereld alleen maar ziet als 'dat hebben we nou eenmaal nodig om die gezondheidskundige boodschap te laten landen', dan heb je het een stukje moeilijker om je boodschap te verkopen dan wanneer je de betrokkenheid van die bestuurlijke omgeving ook ziet als input voor waar je mee bezig bent. (beleidswetenschapper)}

Een teamleider vindt de toegevoegde waarde van de handreiking niet duidelijk en het gebruik wordt niet gestimuleerd. Een werkwijze die als bevorderend voor gebruik wordt gezien, is het doornemen van de handreiking met collega's van GGD en gemeente om passende mogelijkheden voor gebruik en voor het uitproberen van andere werkwijzen op het spoor te komen.

\section{Betrokkenheid management}

Een GGD-beleidsmedewerker, beleidswetenschapper, GGD-manager en -teamleider noemen het gemis aan aansturing vanuit een gedeelde visie tussen management, middenkader en beleidsuitvoering over de 
koers van de GGD-organisatie bij integraal gezondheidsbeleid. Zij willen daar concrete beleidsadviezen aan gemeenten van af kunnen leiden. Deze inhoudelijke aansturing ontbreekt volgens de respondenten in beide GGD-en. Twee beleidsfunctionarissen en een teamleider stellen dat de visie op gemeentelijke regievoering en integraal beleid op lokaal niveau zou moeten voortkomen uit een integrale management- en organisatiestrategie van de GGD (citaat 3). Managers denken verschillend over hun rol als het gaat om aansturing vanuit aanbevelingen in de handreiking. De ene manager beschouwt toetsing van het gebruik van de handreiking als taak van het management, een andere laat het gebruik tot het terrein van de professional.

\section{Kijk die handleiding die moet je ook verbinden aan de strategie van de GGD. Dus dan is het ook nodig dat op dat meer bestuurlijke niveau van de GGD het ook daar een plek heeft, dus dat daar ook de verbinding gelegd wordt naar de omgeving . (beleidswetenschapper)}

\section{De innovatie (de handreiking)}

De handreiking voorziet volgens respondenten vooral in 'wat' gedaan moet worden. Een concrete aanpak voor beleidsadvisering en uitvoering, het 'hoe', is in de handreiking echter nog onvoldoende uitgewerkt. Er wordt een kanttekening geplaatst bij 'evidence based werken' (citaat 4). Een manager en beleidsfunctionaris noemen gebrek aan vertrouwen in het concept 'effectieve interventies', dat volgens hen ook onder collega's bestaat.

4. Ons hangt toch ook een beetje aan dat wij denken dat alles... beïnvloedbaar is... wij geloven nog een beetje in die maakbaarheid van de samenleving, dat die ook maar zeer beperkt is. Want wij zitten in onze eigen val te lopen door die schijn op te wekken dat wij met het vingertje weten wat goed is voor de mens, en tegelijkertijd hebben we er betrekkelijk weinig invloed op... wat ik heel opvallend vind is dat in de gezondheidswereld wordt toch veel meer over evidence-based gesproken en als je dat op de keper beschouwt kom je daar ook niet zo ver mee. Ja wel een beetje, maar toch ook betrekkelijk gering. (manager GGD)

\section{Omgeving, sociale en politieke context}

Drie GGD-beleidsfunctionarissen merken in contacten met gemeenteambtenaren dat de handreiking niet of onvoldoende bij gemeenten bekend is of wordt gebruikt. Gemeenten komen soms niet tegemoet aan de Inspectie-eisen voor gebruik van meer effectieve interventies, vanwege hun beperkte lokale financiële middelen. De gemeenteambtenaar ervaart de handreiking als een extra last waaraan 
hij geen tijd wil besteden, omdat er al een weg is ingeslagen (citaat 5). Volgens de stedelijke ambtenaar staan de middelen voor gezondheidspreventie onder druk binnen de gemeentelijke politieke context, wanneer een incident veel aandacht vraagt. Dit kan een onevenredig groot deel van het budget vergen (citaat 6).

Volgens een manager leidt een te sterke focus op de gezondheidsmissie van de GGD ertoe dat andersoortige doelen van gemeenten ondergeschikt raken en groeit de GGD als publieke dienst onvoldoende mee met een veranderende samenleving. Dit is een belemmering voor een integrale benadering zoals in de handreiking wordt voorgesteld.

Drie respondenten vinden dat er meer aandacht nodig is voor de directe relaties in een politiek-bestuurlijke omgeving, om elkaar beter te kennen en om externe belangen in het eigen beleidsproces van de GGD te betrekken.

5. We zijn eigenlijk aan het voortbouwen gegaan op de lijn die we al jaren geleden ingezet hebben en die is eigenlijk toch van prachtig dat er een landelijke richtlijn is, maar wij kijken toch echt heel erg sterk naar als er flink geld bijkomt om dat allemaal te regelen vind ik het prima, maar als dat niet zo is bepalen we toch wat voor onze gemeente het beste is. (beleidsambtenaar Volksgezondheid regiogemeente)

6. Die hostelperikelen hebben dusdanig hoog op de politieke agenda gestaan, omdat de burgers dus heel boos waren dat die hostels in woonwijken worden gevestigd met drugsopvang, dus daarmee wordt het heel concreet. En als het politiek belangrijk is dan wordt het hier ook belangrijk binnen onze gemeente eh als je ziet wat wij daar aan ambtelijke inzet daar hebben moeten plegen op dat ene onderwerp dan denk je van ja... begrijp je hoe het dan werkt zeg maar, dan werkt het niet meer rationeel... (beleidsambtenaar Volksgezondheid stadsgemeente)

\section{Discussie}

De centrale vraag in het onderzoek was welke factoren in de beleidspraktijk van de GGD-organisatie de adoptie en het gebruik van de Handreiking Gezonde Gemeente belemmeren of bevorderen bij de ondersteuning van het gemeentelijk gezondheidsbeleid. Voor de inventarisatie van die factoren lag het accent op de interne GGDorganisatie, omdat de GGD als gemeentelijke dienst een directe ondersteunings- en adviesrelatie heeft met beleidsafdelingen volksgezondheid van de gemeenten. Daarbij is binnen de GGD gezocht naar individuele perspectieven en taakopvattingen, relevante organisatorische randvoorwaarden en de relaties met gemeenten bij adoptie en gebruik van de handreiking. Respondenten in beide GGDen merken op dat de aandacht voor de handreiking beperkt is. Voor 
professionals en management zijn de voordelen van het gebruik onvoldoende verkend, omdat de vertaling naar concrete toepassing van de handreiking niet heeft plaatsgevonden. De vijf clusters van determinanten voor adoptie en gebruik van innovaties uit het raamwerk van Paulussen et al. (2012) dienen als kader voor bespreking van de resultaten.

\section{Factoren gerelateerd aan de interne organisatie}

Vrijwel alle respondenten uit de twee GGD-en bevestigen dat er sprake is van onvoldoende aansluiting van de handreiking bij de bestaande werkwijze van hun organisatie. Zij vinden dat de GGD zijn visie en werkwijze meer zou moeten afstemmen op wat er onder burgers en politici leeft aan concrete problemen en wensen. Het ontwikkelen van sectoroverstijgend gezondheidsbeleid wordt bemoeilijkt omdat binnen de onderzochte GGD-en een eilandcultuur heerst. Aansturing van professionals vanuit gezamenlijke ambities en de vertaling naar concrete uitvoeringsafspraken is niet de expliciete managementstijl. Voor netwerkorganisaties in het publieke domein geldt echter in het algemeen dat zij voor het realiseren van hun eigen doelen externe partners nodig hebben (Bekker \& Putters, 2003). Hieruit volgt dat profilering van een herkenbare ambitie noodzakelijk is voor een gerichte bijdrage van externe partners aan deze doelen. Een innovatie kan deze profilering dienen via kritische reflectie op bestaande doelen.

\section{Factoren gerelateerd aan de individuele gebruiker}

De verspreiding van kennis over de handreiking blijkt bij de betrokken GGD-en onvoldoende geborgd. Respondenten geven aan dat het verbinden van de handreiking met de eigen bestaande instrumenten het gebruik kan bevorderen, wat nu onvoldoende het geval is. De bereidheid bij de GGD-professionals tot gebruik van de handreiking lijkt samen te hangen met een heldere aansturing over gewenste doelen voor gemeentelijk gezondheidsbeleid.

Bij onderzoek naar planningsgedrag van individuele gebruikers van innovaties wordt een onderscheid gemaakt tussen de factoren kennis, attitude, vaardigheden en sociale invloeden (Cabana et al., 1999). Een weliswaar noodzakelijke, maar doorgaans onvoldoende voorwaarde voor gebruik is kennis en begrip van wat de vernieuwing van de gebruiker vraagt.

De vrije ruimte die respondenten ervaren voor het gebruik van specifieke instrumenten, is aanzienlijk. Het valt op dat vooral managers aangeven dat voor een andere werkwijze specifieke competenties aangevuld moeten worden op het niveau van beleidsadvisering, terwijl door respondenten in beleidsfuncties en uitvoering geen ontbrekende competenties worden genoemd. Hier kan sprake zijn van een voorbehoud om eigen tekorten toe te geven of van 
onduidelijkheid over op te volgen werkwijzen van de handreiking en gevraagde competenties. Beleidsmedewerkers missen op hun beurt betrokkenheid en een heldere aansturing en facilitering op basis van inhoudelijke visie, ambities en doelstellingen vanuit het management. De instrumentaliteit (intrinsieke kwaliteitskenmerken zoals mate van compatibiliteit met bestaande werkwijzen en competenties) van de vernieuwing en taakopvatting van beoogde gebruikers zijn belangrijke determinanten die al vroeg in de adoptiefase geadresseerd moeten worden.

\section{Factoren gerelateerd aan betrokkenheid management}

In dit onderzoek bleek de aan de handreiking gerelateerde taakopvatting tussen de geïnterviewde managers te verschillen. Inhoudelijke betrokkenheid bij de uitvoering van beleidstaken en daaruit voortvloeiende aansturing van professionals wordt door de ene manager wel en door de andere niet als taak of verantwoordelijkheid opgevat.

Uit veel onderzoek komt naar voren dat betrokkenheid van het management een kritische factor is voor het succes of falen van een innovatie (Grol \& Wensing, 2006: 51-52).

Mintzberg en Weggeman beschrijven hoe het formuleren van collectieve ambities in teamverband bevorderend kan zijn voor commitment aan een nieuwe werkwijze op aansturend en uitvoerend niveau en dat dit als bevorderend voor implementatie van werkwijzen kan worden beschouwd (Weggeman, 2008: 17-18). Dit onderstreept het belang van een specifieke determinant voor implementatie van een vernieuwing: het in kaart brengen van beloningsoriëntaties van beoogde gebruikers op verschillende niveaus van de organisatie ondersteunt de adoptie van een vernieuwing.

\section{Factoren gerelateerd aan de innovatie}

Bij de handreiking als instrument wordt het belang van 'evidence' expliciet door meer respondenten op verschillende functieniveaus gerelativeerd. Uit onderzoek naar innovaties is genoegzaam bekend dat beoogde gebruikersgroepen slechts in geringe mate worden gedreven door effectiviteit-overwegingen, zeker bij aanvang van een proces van innovatie. Eerst en vooral willen zij zich een beeld vormen van wat de vernieuwing voor henzelf betekent (Paulussen et al., 2007, hoofdstuk 7 en 10). Innovaties gaan haast per definitie gepaard met gevoelens van onzekerheid. Van daaruit is het begrijpelijk dat bij de fase van initieel gebruik van een vernieuwing bij gebruikers behoefte bestaat aan concrete voorbeelden, die houvast bieden en direct iets opleveren voor de dagelijkse praktijk. De mate waarin een vernieuwing houvast biedt en procedurele helderheid biedt, is een belangrijk aandachtspunt voor de fase van initieel gebruik. Ook het antwoord op de vraag: 'Wat levert het mij op?' weegt daarbij zwaarder 
dan de status van 'evidence' of 'effectiviteit', zoals ook uit dit onderzoek naar voren kwam. De directe opbrengsten kunnen daarentegen tussen de diverse functieniveaus (uitvoering, beleid en management) verschillen. Op uitvoerend niveau is concreet houvast bij interventies prettig als de vraag is: 'Kan ik het wel?' De beleidsfunctionaris wil graag dat het instrument voor de beleidsontwikkeling richting geeft voor de te zetten stappen in het beleidsnetwerk, bij de gemeenteambtenaar tot enthousiasme leidt en partners committeert. Voor de gemeentelijk manager is bijvoorbeeld van belang hoeveel burgers er zichtbaar mee bereikt worden, en de bestuurlijk verantwoordelijke ziet graag maatschappelijke betrokkenheid en politieke stabiliteit.

De ogenschijnlijk tegengestelde uitspraken over de concrete toepasbaarheid van de handreiking (het 'hoe' dat nog onvoldoende is uitgewerkt) en de roep om ruimte voor lokale aanpassing van de werkwijzen wijzen op een ambivalente houding bij GGD-en als het gaat om verwachtingen ten aanzien van het 'hapklare brokken-gehalte' van de handreiking. Deze tegenstelling is wellicht te verklaren uit de verschillende ideeën over de toepassing. Naarmate het netwerk van actoren complexer wordt, zal er meer afstemming nodig zijn over gewenste doelen en werkwijzen en zullen vooraf gedicteerde werkinstructies op meer weerstand stuiten. In de innovatietheorie worden een klein aantal gecommitteerde betrokkenen en korte beslislijnen gezien als bevorderende factoren voor het in gang zetten van een vernieuwing (Fleuren et al., 2002: 56-88). Weerstanden tegen veranderende werkwijzen worden dan beter hanteerbaar. Aan de andere kant geven geïnterviewde beleidsprofessionals aan hoe prettig het zou zijn als de handreiking concrete stappen aanreikt voor beleidsontwikkeling en -advisering. De onzekerheid over en het zoeken naar de juiste weg voor het gemeentelijk gezondheidsbeleid uit zich in de gesprekken op alle functieniveaus. De handreiking wordt door zowel de makers als respondenten gezien als 'ontwikkelinstrument'. De verzamelde informatie en aanbevelingen voor beleidsontwikkeling worden in het veld positief gewaardeerd. Het is echter geen afgerond en gebruiksklaar geheel, wat het lastig maakt de handreiking concreet toe te passen in de praktijk. De procedurele helderheid als algemene theoretische voorwaarde voor succesvolle implementatie blijkt hier niet toereikend en vormt een belemmerende factor van de innovatie.

\section{Factoren gerelateerd aan de sociale en politieke context}

De sociale en politieke context waarin de handreiking moet 'landen' mag complex genoemd worden, vanwege de betrokkenheid van een groot aantal organisaties bij publieke gezondheid.

Gemeenteambtenaren volksgezondheid geven aan dat de middelen om gezondheidsthema's breder onder de aandacht te brengen beperkt zijn. De aandacht voor de handreiking bij de in het onderzoek 
betrokken gemeenten is gering. De actualiteit en urgentie van lokale maatschappelijke vraagstukken maken het voor gemeenten lastiger om vanuit gezondheidskaders (de handreiking) beleid te ontwikkelen. Hieruit volgt het belang van de ruimte voor heen-en-weer denken tussen beleidsontwerp (de innovatie) en praktische beleidsvoering, waarbij een politieke context evenzeer dient als input voor de eigen organisatiedoelen. 'Interactief ontwerpen van beleid' biedt een basis voor implementatie van innovaties in een netwerkorganisatie.

\section{Beperkingen in het onderzoek}

De kwalitatieve resultaten uit de interviews over belemmerende en bevorderende factoren voor implementatie van de handreiking geven opvattingen weer uit een groep respondenten in diverse functies van twee GGD-en, externe partijen en van enkele gemeenten. De herkenbaarheid van resultaten voor andere GGD-en is hierdoor mogelijk beperkt. Om aan deze beperking tegemoet te komen is een theoretisch kader gebruikt om het risico van bias in de resultaten te verkleinen. Voor zover de resultaten en aanbevelingen uit de diepteinterviews aansluiten bij dit theoretisch kader, duiden zij mogelijk op generieke factoren voor het werken met de handreiking, die generaliseerbaar zijn voor implementatie in andere GGD-organisaties. Specifieke kenmerken van de onderzochte regionale GGD-organisaties en de beschreven belemmerende en bevorderende factoren voor implementatie kunnen het proces van professionalisering van de gemeentelijke beleidsadvisering binnen andere GGD-en ondersteunen.

\section{Conclusies en aanbevelingen}

In de interviews zijn zeer diverse belemmerende en bevorderende factoren voor implementatie van de handreiking in de GGD genoemd. In antwoord op de centrale vraagstelling van dit onderzoek worden hier de meest opvallende factoren besproken. Een belemmering voor de integratie van de handreiking in het dagelijks werk van GGD-functionarissen is dat de directe voordelen van het gebruik voor zowel GGD-en als partners nog onvoldoende in beeld zijn gebracht als gevolg van gebrekkige interne verspreiding van kennis over het instrument en het ontbreken van een gedeelde ambitie waarbij de handreiking ondersteunend kan zijn. Ondanks de algemeen positieve waardering door de praktijk voor de compleetheid en visie van de handreiking, zien professionals graag meer concrete vertaling naar het 'hoe' voor het gebruik ervan in de lokale context. De GGD zou deze vertaling (intern en extern) als haar taak kunnen opvatten, maar deze wordt in de bevraagde GGD-en onvoldoende opgepakt. Hierdoor wordt niet alleen binnen de GGD, maar ook bij de gemeenten de systematiek van de in de handreiking aanbevolen werkwijzen gemist, evenals de vraag welke competenties mogelijk gemist worden (RIVM 
et al., 2012).

Interne afstemming over de inhoud van de handreiking op managementniveau wordt door respondenten op uitvoerend niveau gezien als stimulerend voor het gebruik en geldt als aanbeveling voor effectieve implementatie.

De rollen van het management, de teamleiders en professionals in het adoptieproces hangen nauw met elkaar samen. Managers gebruiken de 'autonomie van de kenniswerker' (de professional weet het beste of dient het te weten) als argument om weg te blijven van inhoudelijke aansturing en willen het gebruik van de handreiking niet 'opleggen' aan hun professionals. Als absoluut managementstandpunt is dit een belemmerende factor voor implementatie. Een ambivalente professional ('graag concrete handvatten, maar geen keurslijf') is met dit managementstandpunt niet geholpen. Managers nemen nog geen besluit over de status van de handreiking als 'professionele standaard'. Om de status van de handreiking te achterhalen lijkt het verstandig expliciet te maken of en hoe het instrument de actuele beleidsdoelen van de GGD kan ondersteunen of mogelijk kan bijstellen of aanvullen.

Als de GGD het als taak ziet om het gebruik van de handreiking door GGD, gemeente en partners te stimuleren, dan is aan te bevelen dat GGD-professionals en -managers de beloningsoriëntaties (directe voordelen van het gebruik) voor zowel zichzelf als voor de externe partners achterhalen.

Belemmerend voor gebruik van de handreiking is daarnaast dat korte lijnen voor instructie en beloning vanuit managementkaders en voor coaching tussen leidinggevenden en uitvoerders onvoldoende gewaarborgd lijken. Een bevorderende factor voor implementatie is, wanneer de GGD haar organisatiedoelen voor ondersteuning van het integraal gezondheidsbeleid als gezamenlijke richtinggevende doelen kan benoemen, waaraan managers en professionals zich concreet kunnen verbinden.

Het formuleren van een collectieve ambitie kan de teamgeest versterken door duidelijkheid over de doelen en over een gezamenlijke werkwijze en kan het commitment van managers en professionals vergroten. Een voorwaarde is hier dat het management zich ook door inhoudelijke kaders wil laten leiden en coaching en intervisie voor professionals ondersteunt. 
Bij het vaststellen van ambities en doelen kan ook worden achterhaald of er nog specifieke competenties voor het gebruik (zoals bedoeld) van de handreiking worden gemist. De aanpassingen in werkwijzen en competenties die gevraagd worden voor het gebruik, lijken betrekking te hebben op alle niveaus van de GGD-organisatie.

Bij de vraag naar welke organisatorische randvoorwaarden binnen de GGD een rol spelen bij de adoptie en het gebruik van de handreiking, komen factoren als 'versnippering van uren' en 'onvoldoende afstemming met externe partners' als belemmerend naar voren.

Het veranderen van bestaande werkwijzen naar werkwijzen conform de handreiking kan op kleine schaal worden ingezet, voordat veranderingen breder in de organisatie worden doorgevoerd. Op die manier kunnen de voor- en nadelen van integratie van de handreiking met de eigen voorkeursinstrumenten zichtbaar worden.

Ten slotte kunnen we concluderen dat de GGD-werkwijze beter zou aansluiten bij thema's als 'integrale beleidsontwikkeling' en 'intersectorale samenwerking' in de handreiking, wanneer GGDprofessionals meer investeren in het achterhalen hoe gezondheidsdoelen kunnen bijdragen aan de doelen van andere sectoren of samenwerkingspartners. Daarvoor moeten zij andere sectoren (mensen) beter leren kennen. Voor die investering zien medewerkers nu nog onvoldoende ruimte in de GGD.

GGD-en doen er goed aan de dialoog met andere beleidssectoren te versterken, zowel op professioneel en ambtelijk niveau als op wijkniveau met burgers, om gemeenten te enthousiasmeren voor integraal gezondheidsbeleid en voor een sterkere verbinding van publieke gezondheidsdoelen (Wet publieke gezondheid) met de Wet maatschappelijke ondersteuning.

\section{Literatuur}

Bekker, M.P.M., \& Putters, K. (2003). Sturing van lokaal gezondheidsbeleid: de verknoping van gescheiden netwerken. In V.J.J.M. Bekkers et al. (red.), Handboek sturing in de sociale sector. Den Haag: Elsevier Overheid.

Boeije, H. (2006). Analyseren in kwalitatief onderzoek. Amsterdam: Boom Onderwijs.

Cabana, M.D., Rand, C.S., Powe, N.R., Wu, A.W., Wilson, M.H., 
Abboud, P.C., \& Rubin, H.R. (1999). Why don't physicians follow clinical practice guidelines? A framework for improvement. Journal of the American Medical Association (JAMA), 282(15), 1458-1465.

Coolsma, J. (2003). De uitvoering van beleid. In A. Hoogerwerf \& M. Herweijer (red.), Overheidsbeleid, een inleiding in de beleidswetenschap (pp. 133-151). Deventer: Kluwer.

Fleuren, M., Wiefferink, C., \& Paulussen, Th. (2002). Belemmerende en bevorderende factoren bij de implementatie van zorgvernieuwingen in organisaties. TNO-rapport.

Friese, S. (2012). Qualitative Data Analysis with ATLAS.ti. London.

Grol, R., \& Wensing, M. (2006). Implementatie: Effectieve verbetering van de patiëntenzorg. Maarssen: Elsevier gezondheidszorg.

Hoppe, R. (1999). Policy analysis, science and politics: From 'speaking truth to power' to 'making sense together'. Science and Public Policy, 26(3), 201-210.

IGZ. (2005). Deelrapport De professionele uitvoering van de openbare gezondheidszorg is nog niet goed genoeg. Resultaten van het toezicht in 2003-2004 bij GGD'en en het toezicht bij de Jeugdgezondheidszorg o-4jarigen. Den Haag. Inspectie voor de Gezondheidszorg.

IGZ. (2010). Staat van de Gezondheidszorg - meer effect mogelijk van publieke gezondheidszorg. Utrecht: Inspectie voor de Gezondheidszorg.

Kerkhoff, A.H.M. (2006). Interactief ontwerpen van beleid in de openbare gezondheidszorg. Budel: Damon.

Kwink Groep: Noordink, M. (2013). Evaluatie RIVM - Centrum Gezond Leven. Eindrapport. Den Haag.

Lalonde, M.A. (1974). New perspective on the health of Canadians: a working document. Ottawa: Government of Canada.

Loketgezondleven.nl Bilthoven. RIVM. (2014). Ontleend aan http://www.loketgezondleven.nl/gezondegemeente/gezondheidsbeleid-maken/integraal-beleid/ (http://www.loketgezondleven.nl, versie 2.30).

Mintzberg, H. (1998). Covert leadership: Notes on managing professionals. Harvard Business Review (Reprint nr. 98608). 
Paulussen, Th., Pin, R., \& Mesters, I. (2012). Interventiedisseminatie en -implementatie. In: J. Brug, P. van Asseman \& L. Lechner (red.), Gezondheidsvoorlichting en gedragsverandering, een planmatige aanpak. Assen: Van Gorcum/Open Universiteit.

Paulussen, Th., Wiefferink, K., \& Mesters, I. (2007). Invoering van effectief gebleken interventies. In J. Van Brug, P. Asseman \& L. Lechner (red.), Gezondheidsvoorlichting en gedragsverandering. Assen: Van Gorcum.

RIVM i.s.m. nationale en regionale instellingen. (2012). Competentieprofiel Gezondheidsbevordering en Preventie. Versie 1.o.

Rogers, E.M. (2003). Diffusion of innovations. New York: Free Press.

Stivoro. (2006). Handleiding tabakspreventie in lokaal gezondheidsbeleid. Voor een rookvrije toekomst. Den Haag.

Stivoro, Trimbos-instituut, Voedingscentrum, Rutgers WPF, Consument en Veiligheid, Pharos, SOA AIDS Nederland, \& RIVM. (2010). Handreiking lokaal gezondheidsbeleid: roken, alcohol, overgewicht, depressie, seksuele gezondheid. Bilthoven: RIVM Centrum Gezond Leven.

Termeer, C., et al. (2006). Vitaliseren van gestagneerde organiseerprocessen; Onderzoekend interveniëren met de configuratiebenadering. Management en organisatie, nr. 2, maart/april.

Trimbos-instituut. (2007). Handleiding preventie van depressie in lokaal gezondheidsbeleid. Utrecht.

Van Dijk, S., \& Van Kesteren, D. (2009). Evaluatie handleidingen lokaal gezondheidsbeleid. Bijlage bij het RIVM Rapport 'Leefstijlinterventies in Nederland'. Bilthoven: RIVM Centrum Gezond Leven.

Van Linge, R. (2006). Innoveren in de gezondheidszorg. Theorie, praktijk en onderzoek. Maarssen: Elsevier.

Voedingscentrum. (2007). Handleiding preventie van overgewicht in lokaal gezondheidsbeleid. Den Haag.

Voedsel- en Warenautoriteit. (2007). Handleiding lokaal alcoholbeleid: een integrale benadering. Den Haag.

Weggeman, M. (2003). Terug naar de Rijnlandse werkcultuur. In M. Weggeman, Provocatief adviseren. Schiedam: Scriptum Management. 
Weggeman, M. (2008). Leidinggeven aan professionals? Niet doen! Over kenniswerkers, vakmanschap en innovatie. Schiedam: Scriptum.

Weick, K.E. (1969/1979). The social psychology of organizing. New York: Random House.

(C) Boom Lemma uitgevers 